\section{Innovation in healthcare services: notes on the limits of field research}

\author{
Inovação nos serviços de saúde: apontamentos \\ sobre os limites do conhecimento
}

\author{
Innovación en los servicios de salud: indicaciones \\ sobre los límites del conocimiento
}

Laís Silveira Costa 1

\begin{abstract}
The contemporary context of population aging, its different health and disease characteristics, and the growing incorporation of technologies by healthcare systems have highlighted the need to adjust the healthcare structure as a whole. The defense of a democratic and sustainable system reveals the importance of understanding how changes in healthcare take place. The current article aims to contribute to the understanding of innovation in healthcare services. The study's results indicate that the existence of certain knowledge gaps means that public policies tend to overlook a whole range of innovations normally associated with social change, with a consequent impact on human development, social cohesion, equality, and equity, all issues that are central to the field of public healthcare. The article concludes that the lack of a mature theoretical framework negatively impacts the formulation of such policies, further aggravated in Brazil by growing differences in quality and access between population segments that depend on the public and private healthcare systems.
\end{abstract}

Healthcare Services; Diffusion of Innovation; Healthcare Policy; Sustainable Development; Innovation

\author{
${ }_{1}$ Escola Nacional de Saúde \\ Pública Sergio Arouca, \\ Correspondence \\ L. S. Costa \\ Escola Nacional de Saúde \\ Pública Sergio Arouca, \\ Fundação Oswaldo Cruz. \\ Av. Brasil 4036, Prédio da \\ Expansão da Fiocruz, sala \\ 809, Rio de Janeiro, $R J$ \\ 21040-361, Brasil. \\ lais.costa@fiocruz.br
}




\section{Introduction}

The contemporary context of population aging, its different health and disease characteristics, and the growing incorporation of technologies by healthcare systems have posed some difficult challenges and consequently been the targets of debate of national governments and the World Health Organization (WHO). The adjustment of the healthcare structure to meet new demands, the defense of a democratic system, and the need for this structure to be fully sustainable suggest that changes are indispensable and show the relevance of understanding how processes relating to changes in healthcare are established. This also explains the growing importance of innovation in healthcare as a field. Its importance relates to improvements in the population's well-being and, as a sector intensive in research and development (R\&D), it is associated with international competitiveness, thereby highlighting a range of interests that lend dynamism to its agenda.

Healthcare also has its own particularity in that it represents an important link between the national innovation and the social welfare systems. For this reason, a number of authors 1,2,3,4 have acknowledged that progress made in the healthcare innovation system has certain implications for the economy and society as a whole. This process is not without its contradictions, however. While on the one hand, the expansion of services and the consumer market for industrial products used in care, promotion, and prevention in healthcare represents social gains, on the other it helps meet the demands for capital accumulation in the healthcare industry's private sector 5 . The interests of Capital (no longer limited to industries alone) join forces and exert pressure on the State and, depending on the strength of its own institutions, It is more or less captive to such interests. Policies previously defined at the national level and now increasingly influenced by global value chains not only determine production but influence consumption ideologies, helping shape a social conscience of needs.

Since the end of World War II, there has been a rapid incorporation of technology into healthcare in Brazil and elsewhere around the world, intensified in recent decades through the emergence of new technological platforms linked to biotechnology, nanotechnology, and information and communication technologies. has care has the that exists has beenOn the other handthere are that help and,ingbeing

In recent decades, a trend has gained force in the organization of cost rationalization systems and the shift to primary care as the portal of entry into the system. This trend has been simultane- ous with, and in the opposite direction of another that linked satisfaction, safety, and dignity to modern technologies, but without questioning the conditions of access or the brutal inequality that exists in the use of socially produced goods 6 . Meanwhile, evidence shows that there are various practices that could help decrease costs and improve healthcare efficiency, thereby expanding access, but that these practices are not being implemented 7,8 .One perspective thus increasingly contends that the more technology, interaction, and intervention we have, the better healthcare will be. This view relates to a consumerist practice permeating healthcare systems and documented by the dissemination of innovations without proven effectiveness, fueling cost increases in healthcare systems and more iatrogenic effects $6,9,10,11$. This trend, combined with demographic changes and the characteristics of health and disease processes has raised concerns about the sustainability of universal healthcare systems worldwide. Due to these issues, healthcare systems face the challenge of simultaneously achieving "better care" and "better health for populations" at a "lower cost" 12 , which this article will refer to as the tripod of sustainability.

Overcoming this challenge relates intrinsically to the need for change and thus requires a better understanding of the determinants of innovation in healthcare, since it simultaneously requires lower costs and greater efficiency, suggesting the need to implement changes and introduce social technologies. The social technologies concept refers to products, techniques, and methods as replicable solutions for social change 13,14. Having emerged as the result of a search for new solutions to social problems, its principal characteristic is to contribute to a shared value 13,14

The need to promote important changes in the healthcare system and in medical practices suggests that one should focus on the correlation of heterogeneous forces in the field of healthcare. These changes do not refer exclusively or essentially to technological innovations, the analysis of which is available in other studies 15,16. Such innovations are defined as novelties implemented by the industrial sector that increase the efficiency of the industrial process or that involve a new or improved product 17 . Aside from the occasional comment, these will not be the object of our analysis.

The definition of innovation in healthcare adopted here includes the introduction and intentional application of new ideas, processes, products, or procedures within a goal, group, or organization and whose adoption is relevant to the unit that adopts them and which will signifi- 
cantly benefit the individual, group, or society at large 18,19 .

The proposed study's relevance lies in the need to understand variables related to healthcare systems' sustainability and to help back policies focused on the development of social technologies, which by definition aim at stakeholders' emancipation, focusing primarily on both producers and users 14 . The study thus aims to produce knowledge on innovation in healthcare services, contributing to the democratization of healthcare in a context in which the deconstruction of welfare systems is debated and in which a defined coverage rather than a universal system is defended 20 . That is, this study attempts to back knowledge as the basis for an alternative approach that offers better care and reduced individual costs, without selecting a specific population group, rather than a path that would worsen existing inequities, resulting from the social determinants of health and disease processes.

We propose to furnish backing for the understanding of how innovation in healthcare is diffused, when and why it is disseminated, and what kind of change is important, considering innovation's objectives. We attempt to politicize the idea of the social construction of innovation by incorporating critical theory. The context in which changes in healthcare services occur (or fail to occur) is the object of critical theory that was originally concerned with fomenting emancipatory practices by understanding the imperatives and constraints that provide the dynamics for structural and incremental changes in modern healthcare systems. In this case, critical theory aims to answer an objective question, unveil the basis of the historical process that has reproduced and deepened inequalities in access to healthcare services, and point to possible paths for overcoming them. This critical approach provides a more complex and thus more complete basis for analyzing the dynamics involved in changes in healthcare organizations. It also draws on the analysis of the critical theory of technology by acknowledging that contemporary technologies favor specific ends while obstructing others, such that the democratization of technology involves finding new ways of favoring and prioritizing marginalized values and groups, adopting new technological directions and arrangements 21 .

The article is exploratory, intended to address studies at the meta-theoretical level, and focusing on their theoretical premises for problematizing the nature and characteristics of an adequate critical theory for the theme ${ }^{22}$. The analysis drew on a narrative literature review of diverse fields of study, with scientific databases (SciELO,
MEDLINE via PubMed, Capes - Brazilian Graduate Studies Coordinating Board - portal of theses and dissertations), in addition to incorporating literature from article references.

The results indicate that despite the theme's importance, it has still experienced limited development and lacks a mature theoretical framework. This is due to the limitations themselves in our understanding of innovation in healthcare services, the analysis of which often fails to incorporate persuasion, political variables linked to inherent capitalist interests in the field of healthcare, and the State's role 15,16,23,24,25. The results also point to the need for more in-depth development of critical theory, since studies on the theme do shed light on important dimensions, but these are insufficient for an adequate interpretation of the processes relating to social and cultural changes in healthcare services. Another limitation to this theoretical basis is the fact that it is founded mostly on screening studies, and although innovation is a social process, there are few multilevel and longitudinal studies, suggesting this as a potentially fruitful area for research.

The article consists of three sections, in addition to this introduction. The first, on the theoretical trajectory of studies on innovation in services, problematizes their limitations and their impact on the search for a sustainable model for healthcare systems and society. The second addresses factors that lead to success or failure in the dissemination of innovation in healthcare and the importance of political variables in the dissemination of knowledge. The third provides some remarks and suggests some potential lines of research.

\section{Limitations to the theoretical basis for innovation in services}

The literature review identified various different approaches to the theme, using knowledge produced by the fields of administration, technology economics, sociology, political economy, nursing, and medicine. The results showed the lack of a robust theory of innovation in services as the initial challenge to be dealt with.

One should stress that the interest in studying innovation and the development of its theoretical basis originally considered the central position of manufactured products - and their production processes - in a society marked by the Fordist production model. At the time, the economy's performance was tied to industries, whose capacity to introduce innovations (in products or processes) determined their competitiveness and position in the domestic market. Later, with 
the advent of globalization, industries also impacted their international competitiveness. The importance of studying innovation was established within this context and explains why this theoretical framework developed under the technological paradigm.

Services were viewed then as residual in the economy. Their results were demarcated and measured by their non-belonging to the primary or secondary sectors, spawning the myth of their marginal role, which fell apart to the extent that the world increasingly adopted a flexible production model aimed at efficiency and speed in production, thereby guaranteeing flexibility and agility in the circulation of goods 26 . In recent decades, the level of an economy's services activity (particular knowledge-intensive services) has become increasingly synonymous with the economy's overall performance and has sparked interest in the dynamics of innovation in this sector. Despite the theme's relevance, its study still faces a number of limitations, including the lack of consensus over its typology and the mapping of potential stakeholders in analyzing its dynamics, besides its vague and intangible characteristics. The lack of harmonization of concepts and phases in the innovative process and its determinants are also the result of the complexity of transposing the theory of innovation (originally related to products) to services.

One particular study 27 systematizes the four different theoretical approaches to innovation in services: assimilation (or technicism, according to some authors); differentiation or demarcation (called "services-based" in some studies); inversion (considered services' backlash 28); and the integrative perspective or synthesis.

In assimilation, healthcare services absorb innovation passively, since innovation is defined by the demand and technological incorporation in the segment. The innovation generated thereby is underestimated, since it is conceived as the result of the introduction of technological systems into services, and its concept reflects an inadequate transposition of the theoretical framework used in the analysis of industry, incapable of reflecting the nature of services.

The limitations of this approach sparked the development of a view based on differentiation, which sought to capture innovation based on services' intangible and interactive nature and to develop theories through case studies (new services, management operations, and marketing). According to its proponents, differentiation helps identify innovative activities that are invisible from a technicist perspective 27 . This theoretical approach also incorporates the notion that in the innovative process in services, it is more important to grasp the novelties resulting from the interaction between client and user than the technological incorporations themselves 29 . However, this is also reductionist, limited to identifying some particularities in services' nature and organization.

According to the inversion perspective 28, rather than representing a backward sector, services represent sources of innovation for the entire economy, especially considering the leadership of knowledge-intensive services in innovation in other economic sectors.

Finally, the integrative approach aims to combine goods and services within a single unifying theory on innovation. Its relevance stems from the contemporary context in which manufactured products are mixed in with the characteristics of services and vice versa 27 . In addition, the most important economic projects and social functions have tended to involve the combination of goods, services, and technological and organizational innovations. This formulation aims to encompass important specificities in the sector - the diversity and relational component of services -, incorporating the client opt-out measure into the model, plus immaterial technical characteristics 29 .

However, although studies on innovations in services have expanded, they are still mostly structured around the traditional perspectives (assimilation) that prioritize products and their production processes rather than organizational and market attributes, thereby failing to take a given society's characteristics or power structure into account. This model, focused on manufactured products, faces certain limitations, especially in terms of analyzing technological innovations because the boundaries between product characteristics and the processes of services are becoming increasingly blurred ${ }^{30}$. In addition, the conceptual theoretical fundamentals of innovation in services are based on studies of innovation in the private sector, consequently ignoring the impact of the State's role, and these, therefore cannot be applied to research in the field of public healthcare.

Some authors highlight the leading role of policymakers, through their ability to either encourage or limit the generation, diffusion, and dissemination of innovation 30 . These authors also highlight policymakers' activities in financing basic research and consumers (even influencing the demand for the development of social technologies). In addition, they reaffirm the importance of the government's production of public goods to complement a given innovation. For example, in healthcare, the lack of an adequate technological and communications infrastruc- 
ture can limit progress in the use of telemedicine. Its poor distribution tends, in turn to restrict the access that technology could provide to the favored few.

Economists specializing in innovation have made progress in the incorporation of organizational characteristics (in addition to technological ones), but have paid less attention to the role of politics, power, and persuasion within the scope of their research. This limits the analysis of the processes they define to the generation, diffusion, and dissemination of one innovation to the detriment of another, since it is a technical process, but not exclusively (because it is social, it is also political, by definition).

The inadequacy of this theoretical base has hampered our understanding of the contemporary context and limited the search for a more egalitarian and humane society, as pointed out in a recent study 31 that draws our attention to what the authors call the "innovation gap" and "performance gap". They define the former as the difference between innovation produced by a society and that which traditional indicators (patents and $\mathrm{R} \& \mathrm{D}$ ) are able to measure; analogously, "performance gap" expresses the limits of the measurement of an economy's results related exclusively to its growth in terms of income or gross domestic product (GDP). The authors highlight the impact of these gaps on a services-based economy and expound on the double gap that leaves the relationship between innovation and performance blurred, thus allowing the questioning of the legitimacy of policies and actions focused on fomenting innovations.

The lack of specifics in terms of the boundary between products and services leaves innovation underestimated in all economic sectors. Additionally, the study emphasizes the fact that it is precisely in knowledge-intensive services, like healthcare, that innovation has an even more significant role. Identification of existing gaps led to the design of a theoretical model according to which a given society produces visible innovations - measured using traditional indicators and invisible ones, and this model can be verified by looking at the economy's results. The invisible vectors normally involve non-technological innovations (especially those involving the user's cooperation - ad hoc-, and those referring to the detection of an emerging new field) and are normally tied to social changes and to results related to socioeconomic and ecological sustainability (with a strong impact on human development, social cohesion, equality, equity, and environmental protection) 31 .

Thus, despite the theoretical development seen in recent decades, knowledge gaps in ser- vices-based innovation still persist, revealing more complex relations than those that have been successfully translated into knowledge, and questioning the relevance, quality of diagnosis, and validity of public policies. To maximize the welfare state's functions, government agents must decide where to spend their budgets and which innovative processes should be promoted by public sector institutions 30 . In this context, innovation and performance gaps behave as impediments to achieving the sustainability tripod, since they display shortsightedness in terms of the possible paths to take in order to overcome the challenges of sustainability, democratization, and quality.

\section{The determinants of knowledge dissemination and the challenges to changes in healthcare practices}

Understanding innovation in healthcare services is not without its contradictions. It is limited by the methodological issues addressed in the previous section and by the complexity of transposing the theoretical framework to a knowledgeintensive field with asymmetrical information and a combination of market and public-interest characteristics that coexist in an institutional and political environment, which varies from country to country. Since innovative research is socially determined, it depends on the trajectory of agents that obtain advantages with the systematic accumulation of knowledge and skills to spawn innovative efforts. For this reason, studies on innovation in healthcare focus almost exclusively on industrial settings, which, even today imposes limits on our understanding of innovation in services in both the public and the private sectors 32 .

The innovation process occurs through the learning and introduction of new practices, products, designs, and processes. Sometimes the innovative process is limited to the introduction of new technologies into the organizational context, but this process is often the result of interaction involving multi-stakeholders (organizations, government agencies, universities, research institutes, financial institutions, health professionals, users, and class associations).

The tendency to incorporate changes differs according to whether they are incremental or disruptive 33,34 . Disruptive innovation is the development and introduction of an entirely new product, process, or production format, which may represent a structural break with the previous technological pattern, giving rise to new industries, sectors, and markets, as well as reducing costs and improving existing products' quality. 
Incremental innovation involves the introduction of any type of improvement to a product, process, or production format in a company without necessarily altering its structure; this normally involves more stakeholders in its process and does not significantly alter the status quo in the production environment, so it tends to enjoy greater stakeholder buy-in. When innovations in healthcare seek to create a new organizational structure or practice, they force clinicians to venture outside their familiar environment within the cognitive sciences 18 . This type of innovation - disruptive or radical - tends to suffer a greater degree of resistance, since it requires a whole new range of knowledge attributes, it may sometimes imply infrastructure changes, and normally involves changes in the balance of power 18. In addition, the capacity to innovate relates to the initial position occupied by a firm (and its prior knowledge base) 35 .

As a result of changes in the demographic structure, among other factors mentioned above, studies on the changes needed to achieve healthcare system sustainability have multiplied. Public and private stakeholders have established new cooperative networks to provide more efficient services with higher quality and focused on more demanding patients, while medical and technological advances have offered new opportunities to introduce changes to professional practice. However, literature on the subject points to a striking gap between scientific evidence and its incorporation in practice, which has raised concerns over the costs and avoidable suffering associated with the non-adoption of scientifically validated practices 11. Evidence that healthcare systems only incorporate a small proportion of evidence-based knowledge has sparked interest among researchers, governments, and policymakers to better understand the factors that determine the diffusion and dissemination of one particular innovation as opposed to another.

The growing importance of this new field of knowledge, referred to as the science of "dissemination", “diffusion", or "implementation" 8,36, can also be attributed to the current challenges facing the sustainability of universal healthcare systems. Beyond the analysis of costly technologies spread across systems, this line of research starts with the documentation of numerous evidencebased practices that could theoretically make the system safer, more humane, and cheaper, but which are not disseminated.

Strengthening the diffusion and dissemination of successful innovations is also defended in order to incorporate changes in healthcare management and practice 37 . Understanding the determinants of innovation is crucial for designing strategies to foment "desirable" innovations 38 , corroborating the hypothesis of a lack of legitimacy of policies to foment innovation without their being known. A study on this issue 11 has mapped three categories of influence in the science of diffusion: perceptions of the innovation (perceived benefit from implementing the change, compatibility with values and past trajectory, complexity of the innovation, its testing, and observability; characteristics of the persons that adopt it; and context (communication, incentives, leadership, management). Other studies 39,40 point to its relevance (beyond its effectiveness, its significance in a broader analytical universe); usability (its applicability to cooperation between users, providers, and other stakeholders enables it to be improved and adjusted); and sustainability as the main attributes facilitating or inhibiting innovation in healthcare organizations.

Studies agree that stakeholders are more likely to adopt less complex innovations, amenable to small-scale testing, low-risk, and adaptable to the workplace. Leading factors governing the success of dissemination in healthcare innovation include formal mechanisms to find innovations that should be deployed, the capacity to locate and support innovators, investment in first adopters, ensuring that the activities of these first adopters are visible and thus observable, trust in and encouragement for reinvention and adaptation, the existence of resources favoring change, and leading by example 11 .

Meanwhile, practice-based studies often fail to receive due attention from decision-makers and workers because they tend to be linked to routine activities. Although they can be found throughout healthcare services, they are scarcely visible, even to those that are part of them ${ }^{41}$. This raises certain challenges for companies' efforts to deploy routines and institutionalization, as well as for cumulative learning. Practice-based research depends essentially on personal knowledge, which is difficult to transmit and not very amenable to coding and sharing, as discussed by Polanyi 42 .

To map the social processes that influence how adaptations and innovations occur in surgical settings, a number of researchers 43 systematized three key components: pursuit of improvement, orientation to change, and cultural and material conditions favorable to action. These researchers suggested that personal gain, organizational characteristics, incentives models, and communication platforms have a particular impact on dissemination.

The authors also expressed reservations concerning the possibility of surgeons depositing their findings in a database, since the shared 
knowledge observed in their study suffered a marked influence in the degree of confidence among their peers (a determinant factor in the diffusion of an adaptation in its stages from incubation to maturation) 43 . For physicians as a group to incorporate innovations, whether or not resulting from organizational practice, in their structure, they would have to trust in social surveys, which are not generally assigned much credibility by most practicing physicians 40 . In reality, various studies $11,40,43$ emphasize channels of communication as being critical factors in the theory of dissemination, since physicians tend not to trust in remote sources of authority, which suggests that only social channels tend to be effective.

Administrative authorities also deserve an increasing amount of attention in this decisionmaking arena 44 . The incorporation of certain innovations (instead of others) appears to confirm the existence of a pattern of dependence on an organizational framework, and not merely on the nature of the technology 45. Furthermore, organizational adaptation depends on the continuous pursuit of innovation, allowing for the reconfiguration of internal routines and external supply (of new products, services, and processes) 15,32.

Meanwhile, the associated risk (which may involve permanent discomfort, disability, or even death) and the tendency to prioritize autonomy and reputation lead to a culture of non-transparency that inhibits learning and the generation of innovation 40 . Among the external factors related to the adoption of innovations, a study 40 highlights engagement, motivation, and support by the main stakeholders in the organizational context, in addition to the organizations' participation in external networks and competition. Internal factors include the importance of the leadership of shared knowledge, clarity of objectives, stakeholders' motivation, low stress levels, and the level of available resources, as well as management's demographic characteristics (job stability, education, networking, and opinionmaking). Change is favored when a number of different opinion leaders participate in different phases of the adoption process, from its conception to the details of clinical specifications and definition of applications 40 .

The rationale of the processes that lead to inter-organizational variation in innovative efforts involving new products and organizational changes has resulted in a plethora of studies based on behavioral theory ${ }^{46}$. However, the lack of incorporation of political variables related to the local context has led to a growing perception that the analyses in this theoretical field are somewhat restricted.
Although important, they are insufficient to explain the phenomenon of innovation in healthcare services and to back changes and new policies aimed at more democratic access to healthcare. This highlights the importance of understanding the autonomy of medical practice and its objective expressions - which reaffirm the medical profession's protagonist role - but without failing to examine the dynamics of power struggles between the various traditional and emerging disciplines in the field of healthcare, or indeed, to take other interests into account.

A more recent conceptual development refers to the notion that the basis of evidence favoring certain technologies and practices is often ambiguous and challengeable, requiring continuous interpretation and reformulation 15,16,47. The fact that this evidence often ignores the existence of a bias when analyzing the dynamics of innovation in services would overlook the fact that the institutional structures that constitute innovation networks tend to perpetuate existing cycles 48 .

Analysis of innovations in healthcare services should consider three types of institutional structure and format - public, charitable/community, and private 44 - since it requires an understanding of the potential to adapt to change and alterations in demands. Its assessment allows one to conclude that the role of innovation and its capacity for diffusion are conditioned by a predisposition to adjust to the system's different elements; by the emergence of new health problems; and by changes in expectations, values, and cultural norms and in the economic and political sphere.

Thus, any study of innovation in healthcare services necessarily requires that one map the different stakeholders involved. Various authors $23,24,25$ highlight the need for any such analysis to incorporate the role of a lack of consensus in the hypothetical constructs and in the identification and measurement of the innovation processes into the success or failure of development policies and of the implementation of innovations. Since these studies tend to be concentrated on the field of administration, or conducted by a class of healthcare practitioners, they generally do not incorporate those variables that reflect the influence of forces aimed at economic, technological, and political equilibrium. The importance of a multi-stakeholder study is emphasized by the fact that it addresses the rationale of all the interested parties in the dissemination process.

When an analysis fails to reflect the dominant technologies and interests in the growing healthcare services trade, then those variables that 
mirror the stakeholders' bargaining power are overlooked. To advance this theoretical field, science's lack of neutrality has to be considered 49 , since knowledge is influenced by the existing power structures 21 which currently tend to encourage a consumption profile that cannot be replicated for everyone and which therefore tend to generate exclusion. Non-hegemonic social actors could help alter the direction of changes underway 13 , thereby prioritizing the democratization of healthcare systems.

Thus, when considering the formation of knowledge aimed at the sustainability of universal systems, it is crucial to analyze how the asymmetry of information between the different stakeholders impacts the perpetuation of contemporary challenges. Without access to information, stakeholders (particularly patients) have no way of influencing the development of new solutions 50 , so it is important to make expectations explicit concerning the value and quality of services to users.

The main challenge here is to increase the participation by patients and other stakeholders in the research process, on the basis of their protagonist role in improving the quality of care, adjusting expectations, providing feedback to the system, and selecting pilot projects, among other initiatives. Nevertheless, there is as yet little effort being made and few strategies being adopted to ensure the active involvement of these stakeholders 36 .

The mismatch between supply, demand, and funding sources - shaping the challenges of healthcare systems' sustainability - relates to a certain resistance to macro changes that exists, largely the result of fears of a change in the status quo in this power arena, as described in a study 51 that lists such barriers to change based on the fact that the healthcare model remains centered on the provider (holding users in a passive role). It also highlights the fact that changing to a patient-owned system would encounter barriers from health insurance companies, since it would alter the consumption bias, potentially clashing with the capital gains of this increasingly concentrated and verticalized industry.

It also draws attention to the impact of the financing and payment model, sometimes inconsistent with social technologies; the study mentions that private and public spending are often not synergistic, especially when the former stimulates consumption that frequently siphons resources from the public system and creates unreal and unsustainable expectations. It also identifies the following barriers to macro changes: restrictive regulatory practices, threats of legal action, turf behavior (especially when the inno- vation is disruptive), and the deficient design of national healthcare systems 51 .

Finally, overcoming knowledge gaps on innovation in healthcare services is important because sectors in the health complex are increasingly organized according to market logic, creating their identities in terms of commodities 52 . Capital flow has allowed the formation of large services and welfare oligopolies, which can accentuate the trend towards dual healthcare systems 53,54 , with the aggravation of differences in quality and access for specific services between different population segments that depend on the public and private systems 55 .

In Brazil, research on the dynamics of innovation in hospitals 15 corroborates the limitations of universalization resulting from the transfer of public funds to the private system 51 . Resources that are already scarce in the public sector are increasingly allocated to meet private sector demands, making the healthcare system increasingly unequal, a trend that has intensified in the current context of fiscal crisis, together with the Brazilian healthcare industry's technological dependence ${ }^{15}$.

\section{Final remarks}

The intrinsic difficulties in measuring innovations in services and the contemporaneity of the transition to a post-technological economy have shaped concepts that attribute residual importance to services in the innovation efforts of any given economy. An example of this can be seen in the persistent inability of official statistics producing institutes to measure innovation in services and social technologies. This inability negatively impacts public policymaking, since no visibility is given to a series of innovations and results that are normally associated with socioeconomic and ecological sustainability. Recognition of this issue's importance in post-industrial society has not been sufficient to foment a more robust theory, capable of capturing non-technological innovation variables, and understimating the role of services and social technologies in contemporary society.

This is reflected in the various knowledge gaps detected in a literature review on innovation in healthcare services and in the difficulty of incorporating stakeholders into research priority-setting and dissemination of knowledge in healthcare. The development of this field of knowledge requires longitudinal and multilevel studies with a multi- and interdisciplinary approach, given that nearly every large-scale innovation has characteristics that involve different 
individuals, work groups, organizations, and institutions. Any analysis should incorporate various stakeholders' bargaining and veto power and interests, especially those of the State, given the important relations of reciprocity that exist between the latter and invested capital. The selectivity of State structures not only influences accumulation patterns, but is reciprocally influenced by different stakeholders' previous struggles and strategies.

The limitations inherent in the field of innovation in healthcare services have harmful impacts on the formation of the knowledge base and policymaking aimed at fomenting the changes needed for universal systems' sustainability. This is in a context of changes taking place in the population's health and disease profile, demographic transition, and rapid incorporation of technologies. Evidence indicates that progress in knowledge on innovation in healthcare, aimed at sustainability in universal systems, requires that one expand and effectively implement platforms for registering innovation. There is a need to develop social technologies in which users have an active role in research priority-setting and in the formation of the perceived demand, valuing changes in professional practices (not only those involving technological innovations), and prioritizing research efforts focused on innovation in services.

In Brazil, such initiatives are still incipient, for several reasons. Studies on innovation in services are scarce, existing platforms still focus more on the registration of damage than on valuing change, and the hegemonic tradition limits innovation to the initiatives of industry. In addition, efforts to conduct research translation and consider the bottom-up learning flow, given that processes of change are social and therefore obey neither the pace nor the script of the expectation of top-down changes (whether social or technological). The perpetuation of users' historically passive role in innovation dynamics in healthcare also puts insurmountable limitations on the search for social technologies. This is especially true if one considers the multiple directions that exist in the formation of knowledge and the changes to be disseminated that result from the diversity of contexts and stakeholders with heterogeneous values, a view that entails the active participation of diverse stakeholders involved in the processes of change in healthcare practices.

Thus, despite some relevant efforts being made in Brazil to understand innovation in healthcare services, the results are still at an embryonic stage. Critical theory could be instrumental, since it considers the influence of capitalism on the formation of science to analyze the contradictions between the social and economic interests inherent in this field of knowledge. Critical theory considers bias in the formation of knowledge. It emphasizes the need to expand the range of different interests in this political arena, to approach the elements in the theory's formulation focused on fomenting emancipatory practices, so as to produce more complex diagnoses, since existing approaches still offer insufficient interpretation of the process of historical change involved. Critical theory thus offers analytical references to deal with the conceptual and pragmatic challenges facing studies, as well as a stimulus to emancipatory practices, thereby potentially contributing to research questions and hypotheses on innovation in healthcare services in Brazil. 


\section{Acknowledgments}

The author wishes to thank researcher Ligia Bahia for her valuable comments and both the Brazilian National Research Council (CNPq; grant 405077/2013-0) and the Sergio Arouca National School of Public Health, Oswaldo Cruz Foundation (ENSP/Fiocruz; grant ENSP007-LIV-07) for their support during this research.

\section{References}

1. Gadelha CAG, Maldonado JVSV, Vargas M, Barbosa PR, Costa LS. A dinâmica do sistema produtivo da saúde: inovação e complexo econômico-industrial. Rio de Janeiro: Editora Fiocruz; 2012.

2. Lastres HMM, Cassiolato JE, Arroio A. Sistemas de inovação e desenvolvimento: mitos e realidades da economia do conhecimento. In: Lastres HMM, Cassiolato JE, Arroio A, organizadores. Conhecimento, sistemas de inovação e desenvolvimento. Rio de Janeiro: Editora da UFRJ/Contraponto; 2005. p. 17-50. (Coleção Economia \& Sociedade).

3. Lastres HMM, Cassiolato JE. Inovação e sistemas de inovação: relevância para a área de saúde. RECIIS 2007; 1:153-62.

4. Albuquerque EM, Souza SGA, Baessa AR. Pesquisa e inovação em saúde: uma discussão a partir da literatura sobre economia da tecnologia. Ciênc Saúde Coletiva 2004; 9:277-94.

5. Cordeiro H. A indústria da saúde no Brasil. Rio de Janeiro: Edições Graal; 1985.

6. Lorenzetti J, Trindade LL, Pires DEP, Ramos FRS. Tecnologia, inovação tecnológica e saúde: uma reflexão necessária. Texto Contexto Enferm 2012; 21:432-9.

7. Grol R, Grimshaw J. From best evidence to best practice: effective implementation of changes in patients' care. Lancet 2003; 362:1225-30.

8. Azar J, Adams N, Boustani M. The Indiana University Center for Healthcare Innovation and Implementation Science: bridging healthcare research and delivery to build a learning healthcare system. Z Evid Fortbild Qual Gesundhwes 2015; 109: 138-43.

9. Antman EM, Lau J, Kupelnick B, Mosteller F, Chalmers TC. A comparison of results of metaanalyses of randomized control trials and recommendations of clinical experts: treatments for myocardial infarction. JAMA 1992; 268:240-8.

10. Wennberg JE. On patient need, equity, sulier-induced demand, and the need to assess the outcome of common medical practices. Med Care $1985 ; 23: 512-20$
11. Berwick DM. Disseminating innovation in health care. JAMA 2003; 289:1969-75.

12. Berwick DM, Nolan TW, Whittington J. The triple aim: care, health, and cost. Health Aff (Millwood) 2008; 27:759-69.

13. Dagnino R. Tecnologia social: base conceitual. Ciência \& Tecnologia Social 2011; 1:1-12.

14. Rodrigues I, Barbieri JC. A emergência da tecnologia social: revisitando o movimento da tecnologia apropriada como estratégia de desenvolvimento sustentável. Rev Adm Pública 2008; 42:1069-94.

15. Costa LS, Bahia L. Geração e trajetórias de inovação nos serviços de saúde. In: Gadelha CAG, Noronha JC, Pereira TR, organizadores. Brasil Saúde Amanhã: complexo econômico-industrial da saúde. Rio de Janeiro: Editora Fiocruz; in press.

16. Costa LS, Bahia L. Notas para compreender a interação entre serviços de saúde e inovação: uma revisão da bibliografia. In: Gadelha CAG, Noronha JC, Pereira TR, organizadores. Brasil Saúde Amanhã: complexo econômico-industrial da saúde. Rio de Janeiro: Editora Fiocruz; in press.

17. Organisation for Economic Co-operation and Development; Statistical Office of the European Communities. Oslo manual: guidelines for collecting and interpreting innovation data. 3rd Ed. Paris: OECD Publishing; 2005.

18. Omachonu VK, Einspruch NG. Inovação nos sistemas de atenção à saúde: quadro conceitual. The Innovation Journal: The Public Sector Innovation Journal 2010; 15:1-20.

19. West MA. The social psychology of innovation in groups. In: West MA, Farr JL, editors. Innovation and creativity at work: psychological and organizational strategies. Chichester: Wiley; 1990. p. 309-34.

20. Marten R, McIntyre D, Travassos C, Shishkin S, Longde W, Reddy S, et al. An assessment of progress towards universal health coverage in Brazil, Russia, India, China, and South Africa (BRICS). Lancet 2014; 384:2164-71. 
21. Feenberg A. Critical theory of technology: an overview. Tailoring Biotechnologies 2005; I:47-64.

22. Brenner R, Arrighi G, Harvey D. Teorizando o mundo contemporâneo. Novos Estudos CEBRAP 2008; 81:79-97.

23. Chaudoir SR, Dugan AG, Barr CH . Measuring factors affecting implementation of health innovations: a systematic review of structural organizational provider patient and innovation level measures. Implement Sci 2013; 8:2-20.

24. Velho L. Conceitos de ciência e a política científica, tecnológica e de inovação. Sociologias 2011; 13:128-53.

25. Velho L. Research capacity building for development: from old to new assumptions. Science, Technology \& Society 2004; 9:172-207.

26. Moreira MF, Vargas ER. Compras para a inovação: casos de inovações induzidas por clientes públicos. RAM - Revista de Administração Mackenzie 2012; 13:232-57.

27. Djellal F, Gallouj F, Miles I. Two decades of research on innovation in services. Which place for public services? Structural Change and Economic Dynamics 2013; 27:98-117.

28. Gallouj F. Services innovation: assimilation, differentiation, inversion and integration. In: Bidgoli $\mathrm{H}$, editor. The handbook of technology management. New Jersey: John Wiley \& Sons; 2010. p. 989-1000.

29. Lima DH, Vargas ERV. Estudos Internacionais sobre inovação no setor público: como a teoria da inovação em serviços pode contribuir? Rev Adm Pública 2012; 46:385-401.

30. Windrum P, García-Goñi M. A neo Schumpeterian model of health services innovation. Res Policy 2008; 37:649-72.

31. Djellal F, Gallouj F. Innovation gap, performance gap and policy gap in the service economies. https://hal.archives-ouvertes.fr/hal-01111800/ document (accessed on 13/Jul/2015).

32. Salge TO. The temporal trajectories of innovative search: insights from public hospital services. Res Policy 2012; 41:720-33.

33. Schumpeter JA. The theory of economic development. Cambridge: Harvard University Press; 1934.

34. Harvard Business Essentials. Managing creativity and innovation. Boston: Harvard Business School Press; 2003.

35. Caetano R. Paradigmas e trajetórias do processo de inovação tecnológica em saúde. Physis (Rio J.) 1998; 8:71-94.

36. Schmittdiel JA, Desai J, Schroeder EB, Paolino AR, Nichols GA, Lawrence JM, et al. Methods for engaging stakeholders in comparative effectiveness research: a patient-centered approach to improving diabetes care. Healthcare 2015; 3:80-8.

37. Greenhalgh T, Robert G, Macfarlane F, Bate P, Kyriakidou O. Diffusion of innovations in service organizations: systematic review and recommendations. Milbank Q 2004; 82:581-629.

38. Fleuren MAH, Paulussen TGWM, Dommelen PV, Buuren SV. Towards a measurement instrument for determinants of innovations. Int J Qual Health Care 2014; 26:501-10.
39. Lehoux P, Willian-Jones B, Miller F, Urbach D, Tailliez S. What leads to better health care innovation? Arguments for na integrated policy-oriented research agenda. J Health Serv Res Policy 2008; 13:251-4.

40. Länsisalmi H, Kivimäki M, Aalto P, Ruoranen R. Innovation in healthcare: a systematic review of recent research. Nurs Sci Q 2006; 19:66-72.

41. Salge TO, Vera A. Hospital innovativeness and organizational performance: evidence from English public acute care. Health Care Manage Rev 2009; 34:54-67.

42. Soares MLC. A estrutura do conhecimento tácito em Polanyi: um paradigma pós-crítico para a epistemologia. Lisboa: Universidade Nova de Lisboa; 2012.

43. Apramian T, Watling C, Lingard L, Cristancho S. Adaptation and innovation: a grounded theory study of procedural variation in the academic surgical workplace. J Eval Clin Pract 2015; 21:911-8.

44. Kaluzny AD. Innovation in health services: theoretical framework and review of research. Health Serv Res 1974; 9:101-20.

45. Kaluzny AD, Veney JE. Attributes of health services as factors in program implementation. J Health Soc Behav 1973; 14;124-33.

46. Salge TO. A behavioral model of innovative search: evidence from public hospital services. J Public Adm Res Theory 2011; 21:181-210.

47. Ferlie E, Gabbay J, Fitzgerald L, Locock L, Dopson S. Evidence-based medicine and organisational change: an overview of some recent qualitative research. In: Ashburner L, editor. Organisational behaviour and organisational studies in health care: reflections on the future. Basingstoke: Palgrave; 2001. p. 18-42.

48. Gardner J, Williams C. Responsible research and innovation: a manifesto for empirical ethics? Clin Ethics 2015; 10:1-8.

49. Voirol O. Teoria crítica e pesquisa social: da dialética à reconstrução. Novos Estudos CEBRAP 2012; 93:81-99.

50. Wass S, Vimarlund V. Challenges of stimulating a market for social innovation: provision of a National Health Account Digital Healthcare Empowering Europeans. http://person.hst.aau.dk/ska/ MIE2015/Papers/SHTI210-0546.pdf (accessed on 27/Jul/2015).

51. Gorman D. On the barriers to significant innovation in and reform of healthcare. Intern Med J 2015; 45:597-9.

52. Pereira JCR, Baltar VT, Mello DL. Sistema nacional de inovação em saúde: relações entre áreas da ciência e setores econômicos. Rev Saúde Pública 2004; 38:1-8.

53. Menicucci TMG. Público e privado na política de assistência à saúde no Brasil. Rio de Janeiro: Editora Fiocruz; 2007.

54. Menicucci TMG. O Sistema Único de Saúde, 20 anos: balanço e perspectivas. Cad Saúde Pública 2009; 25:1620-5.

55. Santos MAB, Passos SRL. Comércio internacional de serviços e complexo industrial da saúde: implicações para os sistemas nacionais de saúde. Cad Saúde Pública 2010; 26:1483-93. 


\section{Resumo}

O contexto contemporâneo de envelhecimento e as características de saúde e doença da população, aliados à crescente incorporação tecnológica nos sistemas de saúde têm pontuado a necessidade de adequação da estrutura de atenção. A defesa de um sistema democrático e sustentável evidencia a importância de entender como são estabelecidos os processos relacionados às mudanças na saúde. Neste cenário, o presente artigo visa aprofundar o entendimento sobre inovação nos serviços de saúde. Os resultados da pesquisa indicaram que lacunas no conhecimento levam políticas públicas a negligenciarem uma série de inovações normalmente associadas a mudanças sociais com impacto no desenvolvimento humano, coesão social, igualdade e equidade, temas centrais ao campo da saúde coletiva. E conclui que a falta de um referencial teórico maduro tem impactos deletérios para a formulação dessas políticas, quadro agravado no Brasil, onde são observadas diferenças crescentes na qualidade e disponibilidade de acesso entre os segmentos populacionais dependentes dos sistemas públicos e privados.

Serviços de Saúde; Difusão de Inovações; Política de Saúde; Desenvolvimento Sustentável; Inovação

\section{Resumen}

El contexto contemporáneo de envejecimiento y las características de salud y enfermedad de la población aliados a la creciente incorporación tecnológica en los sistemas de salud, ha apuntado la necesidad de adecuación de la estructura de atención. La defensa de un sistema democrático y sostenible evidencia la importancia de entender cómo se establecen los procesos relacionados con los cambios en la salud. En este escenario, el presente artículo tiene por objetivo profundizar en el entendimiento sobre la innovación en los servicios de salud. Los resultados de la investigación indicaron que algunas lagunas en el conocimiento conducen a las políticas públicas a ser negligentes con una serie de innovaciones, normalmente asociadas a cambios sociales con impacto en el desarrollo humano, cohesión social, igualdad y equidad, temas centrales en el campo de la salud colectiva. Y concluye que la falta de un marco referencial teórico maduro tiene impactos devastadores para la formulación de esas políticas, cuadro agravado en Brasil, donde se observan diferencias crecientes en la calidad y disponibilidad de acceso entre los segmentos poblacionales dependientes de los sistemas públicos y privados.

Servicios de Salud; Difusión de Innovaciones; Política de Salud; Desarrollo Sostenible; Innovación
Submitted on 14/Sep/2015

Final version resubmitted on 22/Feb/2016

Approved on 22/Feb/2016 